\title{
The protective effects of sodium hyaluronate on corneal injuries induced by chlorinated water in adult male rabbits : A histological and immunohistochemical study
}

\author{
Original \\ Article \\ Ayman M. Mousa ${ }^{1,2}$, Abeer M. El-Mahalaway ${ }^{1}$ and Rania E. El-Desoky ${ }^{1}$ \\ ${ }^{\prime}$ Department of Histology and Cell Biology, Faculty of Medicine, Banha University, Banha, \\ Egypt. \\ ${ }^{2}$ Department of Basic health Sciences, CAMS, Qassim University, Kingdom of Saudi Arabia.
}

\begin{abstract}
Introduction: Chlorinated-water-induced corneal wounds lead to reduced transparency and disability of the cornea. Sodium hyaluronate $(\mathrm{SH})$ is a natural lubricant with unique hygroscopic properties that control tissue hydration for topical eye care with excellent use as an ophthalmic product.

Aim of the work: To evaluate the protective effects of sodium hyaluronate on corneal injuries induced by chlorinated water in adult male rabbits.

Materials and Methods: A total of 20 adult male rabbits were divided equally into four groups treated with 2 drops of sodium hyaluronate on the corneal surface of both eyes two times daily for one month as follow: Group I (G1) was control group treated with distilled water, group II (G2) treated with chlorinated water, group III (G3) treated with SH while, group IV (G4) was treated with 2 drops of SH then 2 drops of chlorinated water. The corneas were excised and processed for histological and immunohistochemical study.

Results: G2 showed epithelial thinning with some areas of cellular ulceration. Disturbance of normal stromal architecture, wide separation of collagen fibers and few degenerated keratocytes were noticed. In addition, a significant decrease of BCL-2 immunoexpression was observed in the cytoplasm of corneal epithelial cells $(P<0.01)$. G3 and G4 showed improvement in the histological and immunohistochemical changes described in G2.

Conclusion: Chlorinated water was harmful to the cornea and SH eye drops proved to minimize these corneal complications. Therefore, application of SH eye drops before swimming is recommended to flush chlorine drops away and to allow the tear film to remain over the cornea.
\end{abstract}

Received: 17 March 2018, Accepted: 14 June 2018

Key Words: Chlorine, cornea, sodium hyaluronate.

Corresponding Author: Ayman M. Mousa, Department of Histology and Cell Biology, Faculty of Medicine, Banha University, Banha, Egypt, Tel.: 00966598146171, E-mail: aymandermatoloy@gmail.com.

ISSN: $1110-0559$, Vol. 41, No.2

\section{INTRODUCTION}

Corneal wound is a common worldwide eye illness that led to various forms of pathological alterations; however, it has not satisfactory treatment modalities ${ }^{[1]}$.

The unique location of cornea, at front of the eye makes it the first part of the visual system liable to damage from many injurious agents as ultraviolet ray exposure to physical wounds and bacterial infections. So, healing of a corneal wound is very important for preserving homeostasis of the cornea to preserve our vision by mechanical and chemical barriers, which protect the intraocular tissues of the eye $\mathrm{e}^{[2]}$.

Normal corneal hydration is vital for preservation of corneal transparency and corneal epithelial or endothelial injuries through many external influences that change the mechanisms, essential for maintaining natural corneal hydration and transparency ${ }^{[3]}$.

The cornea is composed of five layers including, the wet corneal epithelial surface with external tear film, Bowman's membrane, corneal stroma that forms $90 \%$ of corneal thickness, Descemet's membrane and finally the endothelium that extracts water from the stroma to maintain the uniform collagen matrix arrangement ${ }^{[4]}$.

Corneal transparency depends on multiple agents, which have a vital function in conservation of corneal transparency and normal corneal function such as rapid epithelial renewal, preservation, constitutional integrity, relative dehydration of stroma and absence of blood vessels with normal metabolism of keratocytes and endothelial cells ${ }^{[5]}$. 
The tear film coating the outer corneal surface has three layers of lipid, aqueous and mucous. The lipid layer has oils, while the aqueous layer contains water with proteins and the mucous layer has proteins only ${ }^{[6]}$.

Chlorine (Cl2), a common chemical disinfectant from the halogen family with a characteristic smell, is used to treat water of drinking and swimming pools due to its easy application, effective germicidal properties and low $\operatorname{cost}^{[7]}$. It has a vital role in developed countries for handling of water and eradication of waterborne diseases, such as cholera, typhoid and dysentery ${ }^{[8]}$.

Chloramines are volatile materials that liberated into the atmospheric air causing multiple inhalation side effects and swimming pool chlorinated water reacts with corneal proteins to chlorinate them ${ }^{[9]}$.

Many therapeutic strategies "e.g. application of steroids, contact lenses and epidermal growth factors" are studied to preserve integrity of epithelium that prevent corneal stromal ulceration. However, the best medical therapy to protect the cornea remains controversial and has not been established yet ${ }^{[10]}$.

Hyaluronan is an active biological polymer that converts into nano-particles ${ }^{[1]}$ and $\mathrm{SH}$ is a new glycosaminoglycan in epithelial, connective and nervous tissues with a visicoenhancer and hygroscopic properties that control tissue hydration in topical eye care formulations ${ }^{[12]}$.

The polyanionic form hyaluronan is present on the corneal endothelium, aqueous and vitreous humor with a high affinity to specific receptors with a lubricant and water retaining properties that make it appropriate for employment in contact lenses, ophthalmic drugs and treatment of dry eye complications ${ }^{[13]}$.

In the current research, we aimed to evaluate the protective effects of Sodium hyaluronate on corneal injuries induced by chlorinated water in adult male rabbits.

\section{MATERIALS AND METHODS}

Twenty adult male "3-months-old" white New Zealand adult rabbits weighing 1-1.5 kg were used in this study. They obtained from and settled at the Animal House of the Faculty of Veterinary Medicine, Benha University, Egypt. Rabbits were kept under $24^{\circ} \mathrm{C}$ with $12 \mathrm{~h}$ light/ $12 \mathrm{~h}$ dark cycle, fed standard diet for rabbits with water ad-libitum.

The experimental protocol was revised and all ethics rules for animal management monitored by the Scientific Research Ethics Committee at Faculty of Medicine Benha University.

\section{Chemical reagents:}

1- Chlorinated water container (containing $0.5 \mathrm{mg}$ of chlorine $/ \mathrm{L}$ at $\mathrm{pH}$ 6.8) purchased from General Oceanics Inc., Cairo, Egypt.

2- $\mathrm{SH}$, eye drops of (Polyfresh $2 \mathrm{mg} / \mathrm{ml}$ at $\mathrm{pH}$ 6.8) manufactured by Orchidia Pharmaceutical Co., Cairo, Egypt.

\section{Experimental design:}

The rabbits were divided into four groups ( 5 rabbits each treated with two eye drops on corneal surface of both eyes two times daily for one month) as follow:

1- G1 was the control group, 5 rabbits were treated with distilled water (DW)

2- G2 (chlorine treated group) included 5 rabbits treated with chlorinated DW $(0.5 \mathrm{mg} \text { of chlorine } / 1 \mathrm{~L})^{[14]}$.

3- G3 (SH treated group) 5 rabbits were treated with SH $0.1 \%[15]$.

4- Rabbits of G4 (protected group) were treated with two drops of SH $0.1 \%$ followed by two drops of chlorinated DW as in G2 and G3.

All rabbits were sacrificed under general anesthesia by ether inhalation (Spofa; Prague) at the end of experimental period then the eye balls were dissected, excised and corneas were prepared for histological and immunohistochemical investigations $^{[16]}$.

\section{1-Light microscopic study:}

A-Histological study: Corneas of all rabbits were fixed in $10 \%$ formalin for 24 hours then; five $\mu \mathrm{m}$-thick paraffin sections were prepared, processed and stained to examine the corneal histological details by hematoxylin and eosin stain (H\&E) and collagen fibers by Masson trichrome stain $^{[17]}$.

B-Immunohistochemical study: The anti-apoptotic effect of BCL-2 was detected immunohistochemically by the monoclonal anti-rabbit BCL-2 primary antibody (Santa Cruz Biotechnology, California, USA) which appeared as a brown cytoplasmic reaction. Avidin-biotin peroxidase method followed by DAB chromogen (Dako, Denmark) on the slides and hematoxylin counter stain of sections were performed. The specific primary antibody was substituted by phosphate-buffered saline for negative control, while, tonsillar sections were used as a positive control ${ }^{[18]}$. 


\section{2-Morphometric study and statistical analysis:}

Ten slides from ten different specimens of each group were examined and ten non-overlapping fields were measured from each slide by image analysis computer system (Leica, UK) at Faculty of Medicine, Benha University.

The mean corneal epithelial thickness/pixels, the mean total corneal thickness/um and the mean area percentage of BCL-2 immuno-expression at a magnification of $\times 1000$ were calculated using the image-Pro Plus program version 6.0 (Media Cybernetics Inc., Maryland, USA).

The experimental data was recorded and analyzed by using the IBM SPSS Statistics software for Windows, Version 20 (IBM Corp., USA), then ANOVA test was applied to compare the differences between groups.

The data was evident as mean value $(\mathrm{M}) \pm$ standard deviation (SD) and differences were significant at $\boldsymbol{p}<\mathbf{0 . 0 1}$.

\section{RESULTS}

\section{1-Light microscopic results A-Histological changes:}

Corneal sections of G1 stained with H\&E in Figs (1, 2 and 3) showed five distinct layers (outer non keratinized stratified squamous epithelium with smooth regular surface, thin homogenous acidophilic Bowman's membrane beneath the epithelium, intermediate non vascular stroma formed of regular collagen fibers and keratocytes with flat nuclei dispersed in the ground substance among the stromal lamellae, thin homogenous acidophilic Descemet's membrane lined with a single layer of cells with flat nuclei on its posterior surface).

While, corneal sections of G1 stained with Masson trichrome stain showed regular bundles of parallel collagen fibers (Fig.4).

Corneal sections of $\mathrm{G} 2$ stained with $\mathrm{H} \& \mathrm{E}$ revealed superficial epithelium with some areas of cellular loss.
Some epithelial cells were distorted while others were vacuolated and degenerated. Stroma showed abnormal structure with marked disruption and separation of collagen fibers by wide spaces while, Descemet's membrane was thin and lined by endothelium with irregular rounded nuclei (Figs. 5, 6 and 7).

Meanwhile, corneal sections stained with Masson trichrome in G2 showed marked disruption and separation of collagen fibers by wide spaces (Fig.8).

On the other hand, examination of corneal sections from G3 stained with H\&E and Masson trichrome showed a histological picture similar to that observed in G1.

While, examination of G4 corneal sections stained with H\&E and Masson trichrome revealed a structure nearly similar to G1 corneal sections.

The corneal epithelium showed nearly normal epithelial thickness with thin Bowman's membrane. Stroma showed regular collagen fibers and normal keratocytes while Descemet's membrane and corneal endothelium were normal (Figs. 9, 10 and 11).

Moreover, corneal sections of G4 stained with Masson trichrome showed mild stromal disruption of collagen fibers with minimal spaces in between them (Fig.12).

\section{B-Immunohistochemical changes:}

G1 and G3 sections showed marked brown cytoplasmic immunoexpression of BCL-2 in corneal epithelial cells (Fig.13) while, G2 sections had a weak immunoexpression of BCL-2 in corneal epithelial cells (Fig.14) and G4 sections showed a moderate immunoexpression of BCL-2 in corneal epithelial cells (Fig.15).

\section{2-Morphometric results and statistical analysis:}

The means of corneal epithelial thickness/pixels, total corneal thickness/um and area percentage of BCL2 immuno-expression were significantly decreased $(P<0.01)$ in $\mathrm{G} 2$ compared with $\mathrm{G} 1$ as shown in table $(1)$ and histogram (1) but there was a non- significant decrease $(P<0.01)$ in G3 and G4 compared with G1.

Table 1: is showing the means and \pm SD of corneal epithelial thickness/pixels, total corneal thickness/um and area percentage of BCL2 expression in all experimental groups.

\begin{tabular}{|c|c|c|c|c|c|}
\hline & & GI & G II & GIII & \\
\hline \multirow{2}{*}{ Corneal epithelial thickness (in pixels) } & Mean \pm SD & $116.92 \pm 2.49$ & $50.35 \pm 2.37$ & $102.21 \pm 1.42$ & $97.88 \pm 1.19$ \\
\hline & $P$ value & & $0.000 * *$ & $0.176^{*}$ & $0.140^{*}$ \\
\hline \multirow{2}{*}{ Total corneal thickness/um } & Mean \pm SD & $54.52 \pm 2.12$ & $30.11 \pm 2.17$ & $53.01 \pm 1.42$ & $51.48 \pm 1.19$ \\
\hline & $P$ value & & $0.000 * *$ & $0.220^{*}$ & $0.195 *$ \\
\hline \multirow{2}{*}{$\begin{array}{l}\text { Area } \% \text { of BCL2 immuno-expression } \\
\text { in corneal epithelial cells }\end{array}$} & Mean \pm SD & $8.47 \pm 0.37$ & $2.22 \pm 0.26$ & $8.40 \pm 0.44$ & $7.83 \pm 0.33$ \\
\hline & $P$ value & & $0.000 * *$ & $0.130^{*}$ & $0.115^{*}$ \\
\hline
\end{tabular}

$\mathrm{SD}=$ Standard deviation, Non-significant*, Significant** for G II, III and IV compared with GI. 


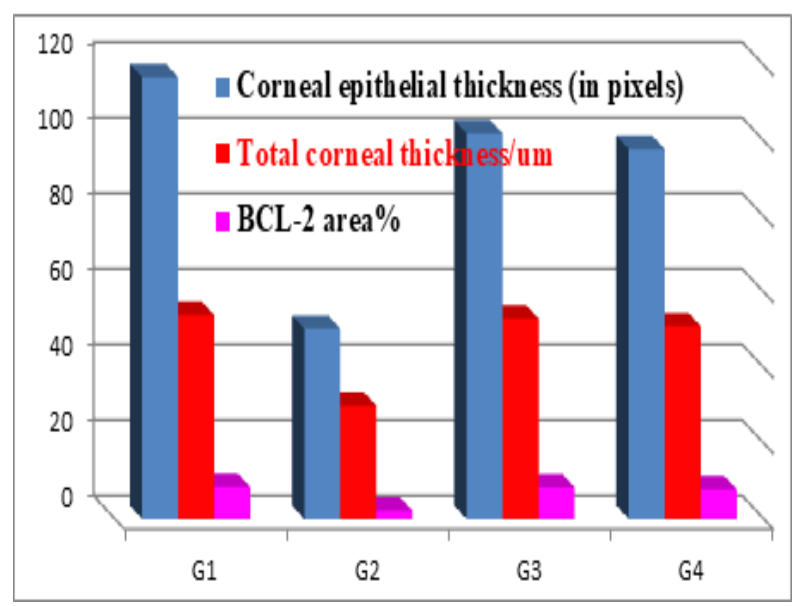

Histogram 1: Showing the means and $\pm \mathrm{SD}$ of corneal epithelial thickness/pixels, total corneal thickness/um and area \% of BCL2 expression in all experimental groups.

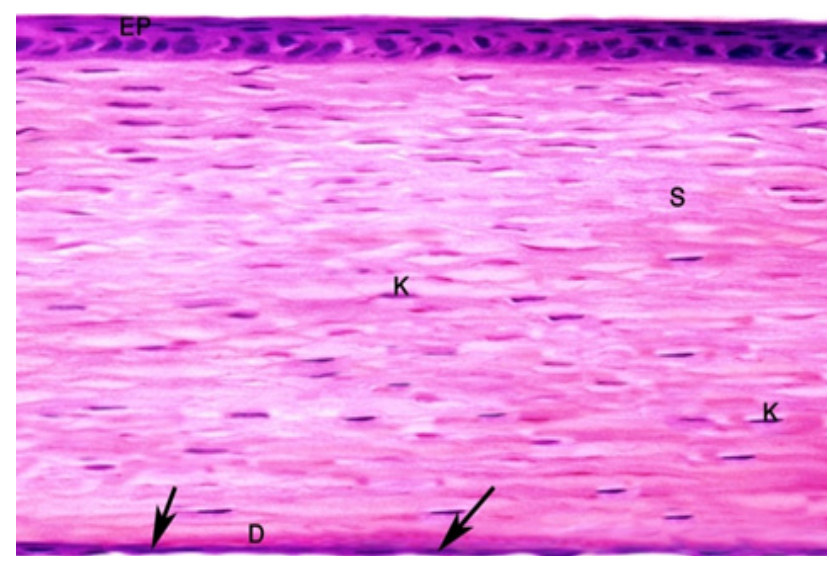

Fig. 1: A photomicrograph of G1 corneal section showing stratified squamous epithelium (EP), stroma (S) of regular collagen fibers and fusiform keratocytes (K). Descemet's membrane (D) is lined by flat endothelial cells (arrow)

(H \& E X 400).

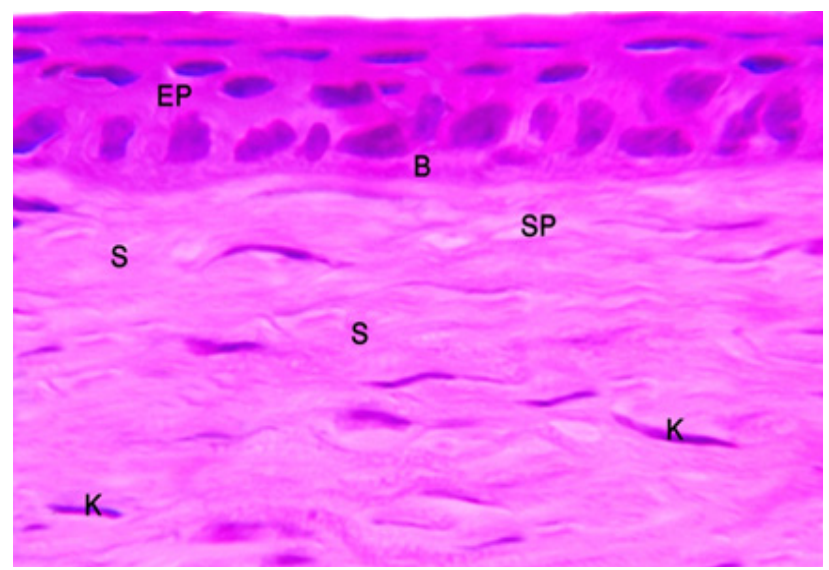

Fig. 2: A photomicrograph of G1 corneal section showing stratified squamous epithelium (EP) with smooth regular surface and resting on a thin intact homogenous acidophilic Bowman's membrane (B). Stroma (S) has regular collagen fibers and fusiform keratocytes (K)

(H \& E X 1000).

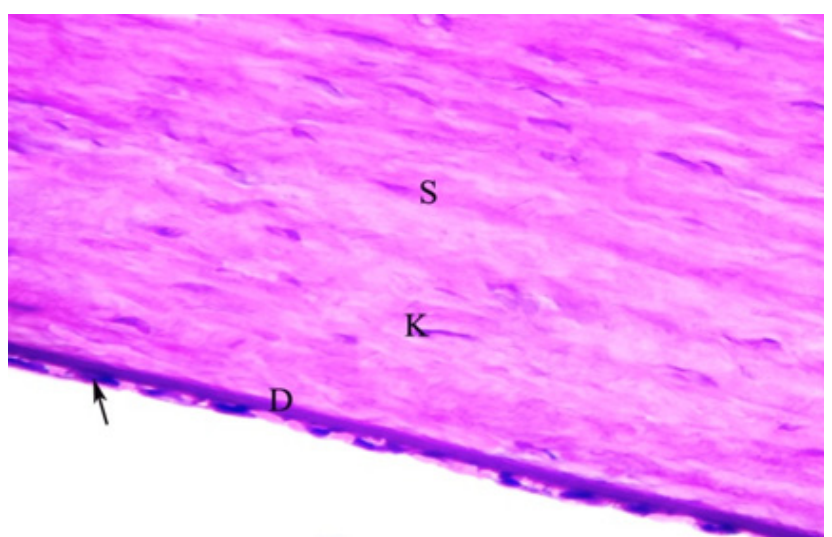

Fig. 3: A photomicrograph of G1 corneal section showing part of corneal stroma (S) with regular collagen fibers and fusiform keratocytes (K). The inner endothelial cells (arrow) have flat nuclei and rest on a thin Descemet's membrane (D)

(H \& E X 1000).

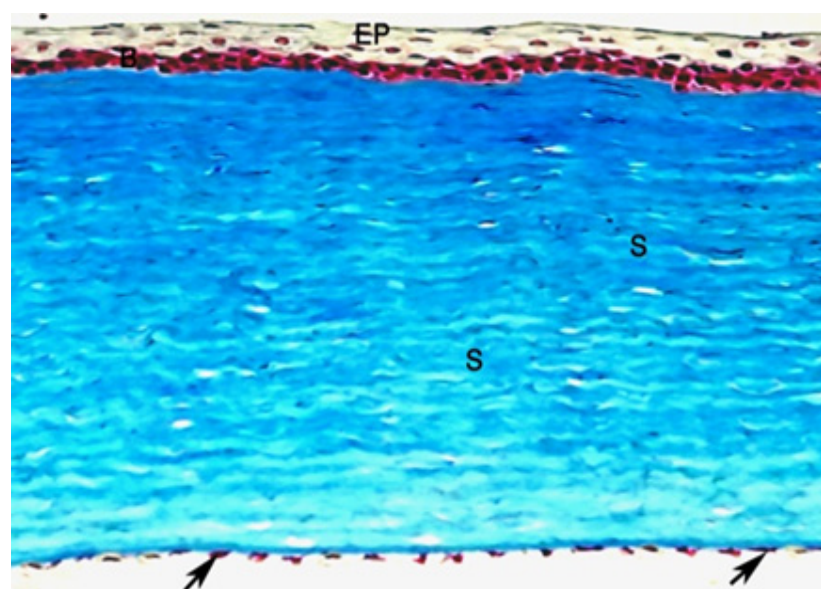

Fig. 4: A photomicrograph of G1 corneal section showing stratified squamous epithelium (EP) resting on a thin intact Bowman's membrane (B), Stroma (S) with regular collagen fibers and normal endothelial cells (arrow)

(Masson's trichrome X 400).

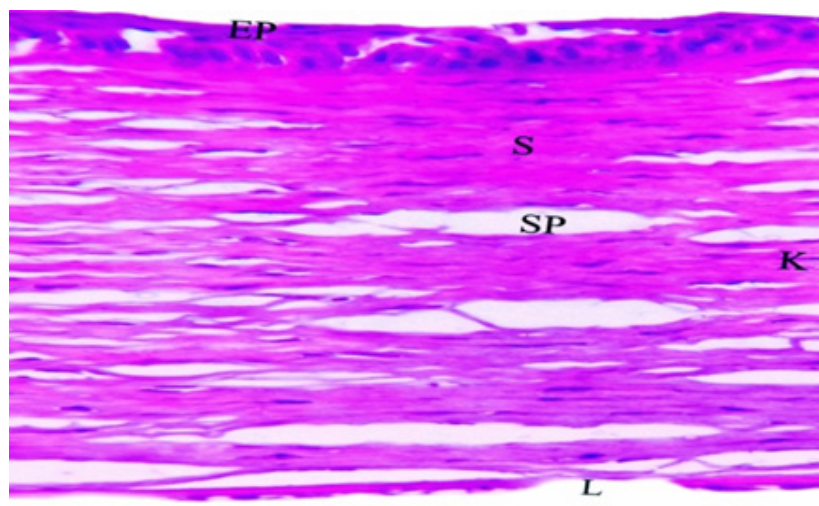

Fig 5: A photomicrograph of G2 corneal section showing stratified squamous epithelium (EP) with some areas of cellular loss. Stroma (S) has few keratocytes (K) and wide spaces (SP) separating irregular collagen fibers. Descemet's membrane at some portions appears thin with loss of endothelial cells (L)

(H\&E X 400) 


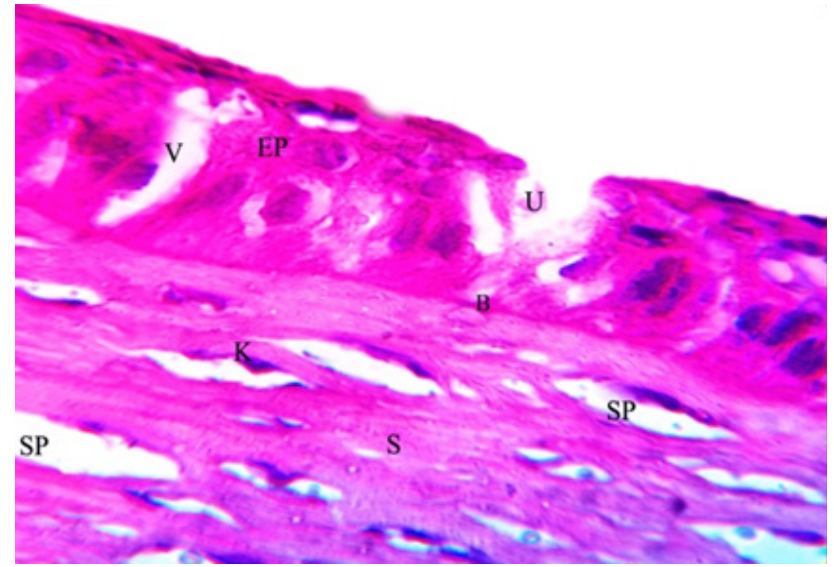

Fig. 6: A photomicrograph of G2 corneal section showing irregular stratified squamous epithelium (EP) with vacuolation (V) and ulceration (U) of some surface epithelial cells. Bowman's membrane (B) is thin and stroma (S) shows wide spaces (SP) with few keratocytes $(\mathrm{K})$

(H \& E X 1000).

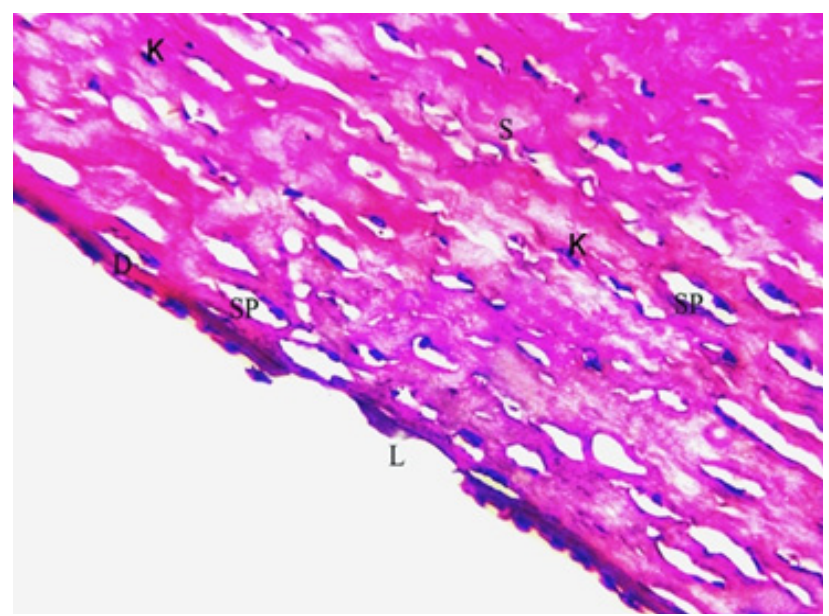

Fig. 7: A photomicrograph of G2 corneal section showing part of the stroma (S) with few keratocytes $(\mathrm{K})$ and irregular collagen fibers separated by wide spaces (SP). Descemet's membrane (D) appears thin with focal loss of endothelial cells (L) at some portions

$(\mathrm{H} \& \mathrm{E} X \mathrm{1000})$

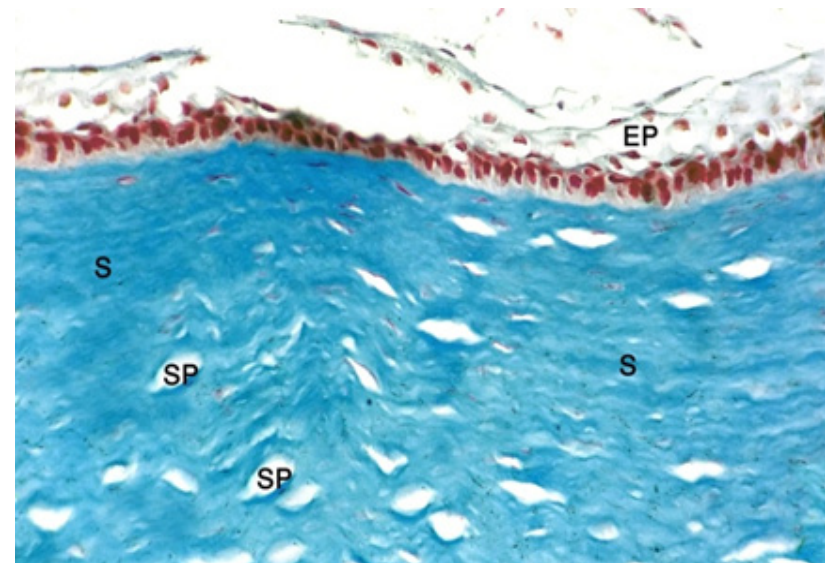

Fig. 8: A photomicrograph of G2 corneal section showing ulcerated stratified squamous epithelium (EP) and stroma (S) has irregular collagen fibers separated by wide spaces (SP)

(Masson's trichrome X 400).

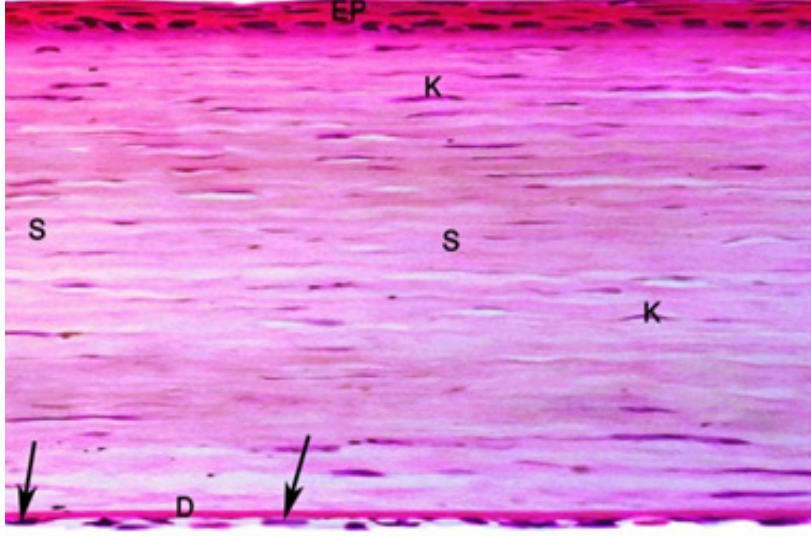

Fig. 9: A photomicrograph of G4 corneal section showing normal stratified squamous epithelium (EP) with smooth free surface. Stroma (S) has regular collagen fibers with narrow spaces and normal keratocytes (K). Descemet's membrane (D) and endothelial cells (arrow) are nearly normal (H\&E X 400).

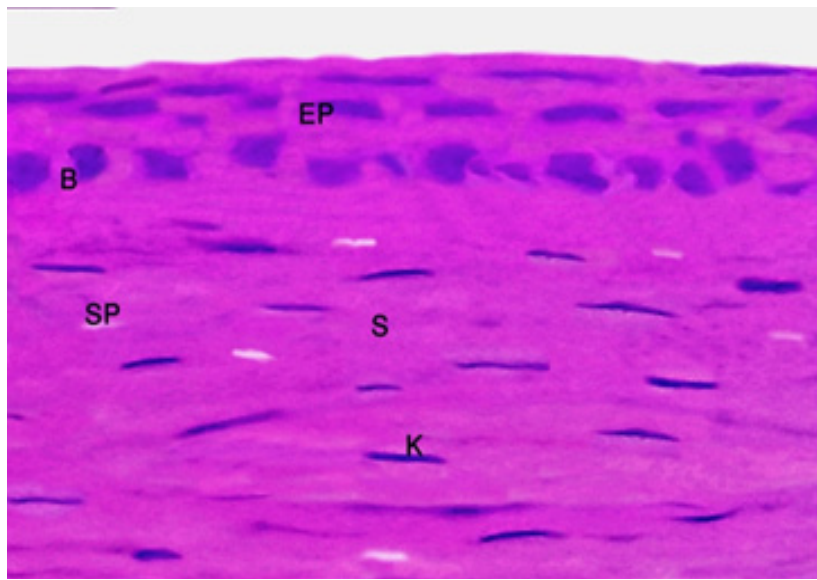

Fig. 10: A photomicrograph of G4 corneal section showing normal stratified squamous epithelium (EP) with smooth free surface and intact Bowman's membrane (B). Stroma (S) shows regular collagen fibers with narrow spaces (SP) and normal keratocytes $(\mathrm{K})$

(H \& E X 1000).

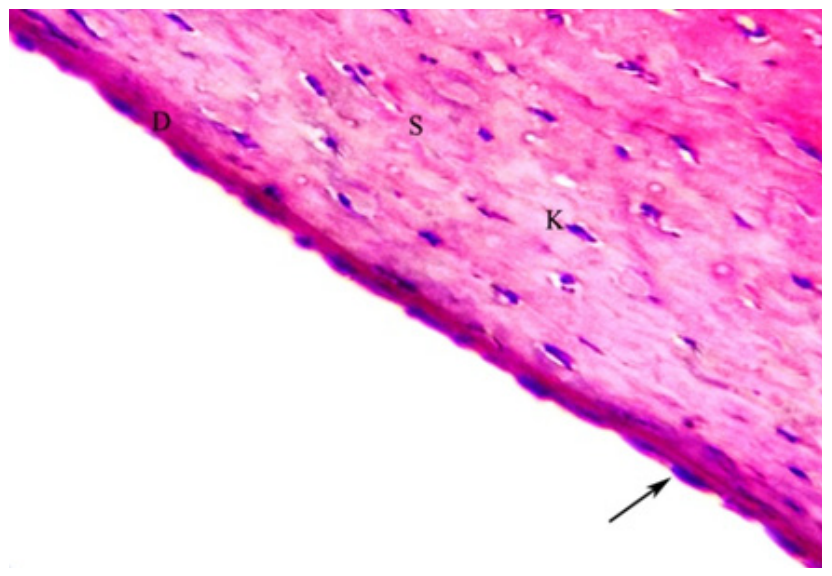

Fig. 11: A photomicrograph of G4 corneal section showing corneal stroma $(S)$ with normal keratocytes $(K)$, regular collagen fibers and narrow spaces. Descemet's membrane (D) and endothelial cells (arrow) are normal

(H \& E X 1000). 


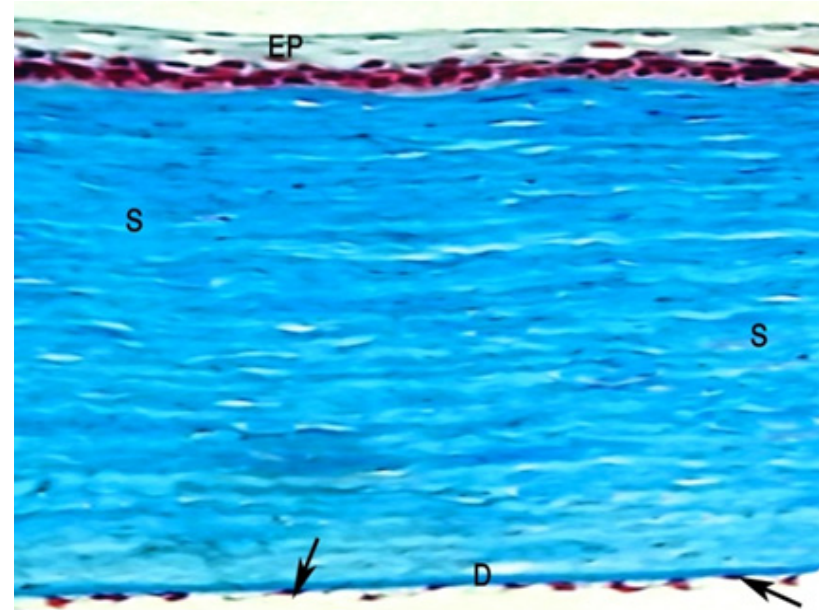

Fig. 12: A photomicrograph of G4 corneal section showing normal stratified squamous epithelium (EP) with smooth free surface, stroma (S) with parallel collagen fibers, thin Descemet's membrane (D) and normal endothelial cells (arrow)

(Masson's trichrome X400).

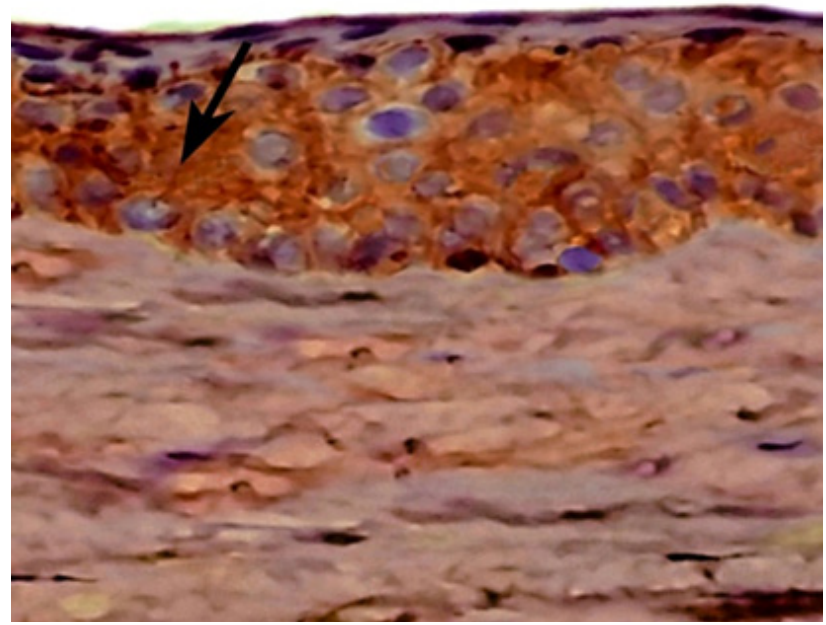

Fig. 13: A photomicrograph of G1 corneal section showing marked immuno-expression of BCL-2 in the cytoplasm of epithelial cells (arrow) (Immunostaining of Bcl-2 X 1000).

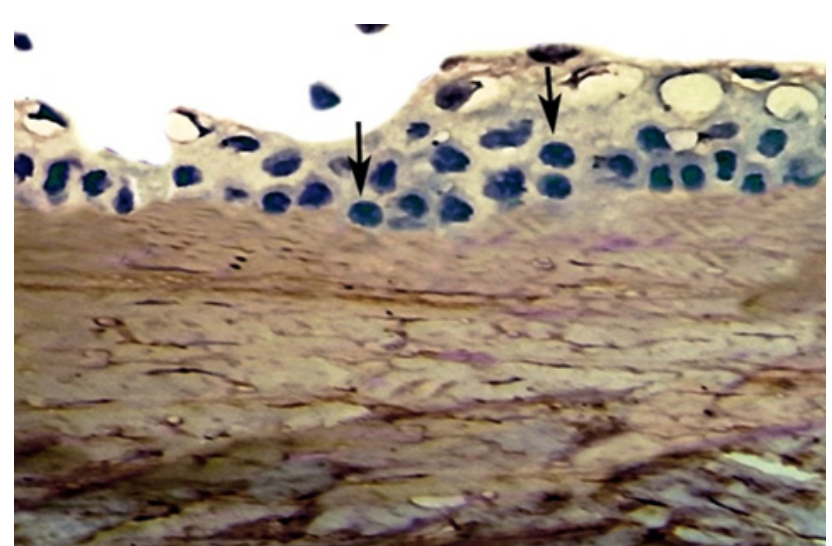

Fig. 14: A photomicrograph of $\mathrm{G} 2$ corneal section showing weak immuno-expression of BCL-2 in the cytoplasm of epithelial cells (arrow)

(Immunostaining of Bcl-2 X 1000).

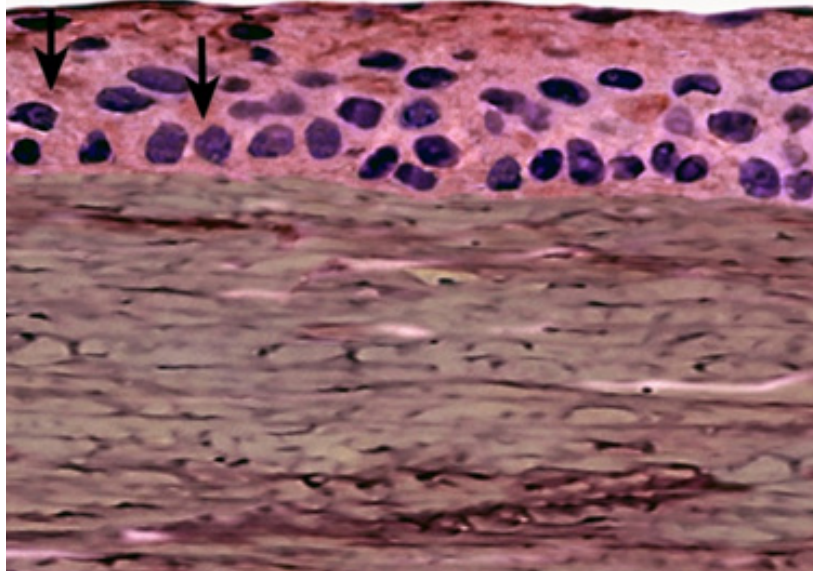

Fig. 15: A photomicrograph of G4 corneal section showing moderate immuno-expression of BCL-2 in the cytoplasm of epithelial cells (arrow) (Immunostaining of Bcl-2 X 1000).

\section{DISCUSSION}

Cornea is the frontal part of the eye that protects and supports it from external hazards as corneal epithelium protects the eye from erosions and acts as a physical barrier against pathogenic invasion and loss of fluids ${ }^{[15]}$.

In the present study, the corneal epithelium of G2 showed distortion of some epithelial cells, while others were vacuolated and degenerated with few areas of cellular loss.

In addition, loss of normal corneal stromal architecture with keratocytes degeneration was noticed. These findings were in accordance with previous investigators who observed decrease of corneal thickness after contact with chlorinated water, as a result from corneal dehydration and corneal tear film dysfunction ${ }^{[19,20]}$.

Richardson and his colleagues described that abnormal arrangement of corneal surface epithelial cells and shape of their nuclei allowing DNA damage in corneal tissue following exposure to chlorinated water ${ }^{[21]}$. Others explained the epithelial thinning by cellular degeneration, loss of dead cells with failure of cellular proliferation and regeneration $^{[22]}$.

In the current study, corneas of G2 showed disruption of normal stromal architecture, few keratocytes, irregular collagen fibers separated by wide spaces and corneal stromal edema.

Luyckx and Baudouin attributed corneal stromal edema to reduction of sodium and potassium-dependent ATPase enzyme levels, which is the main pathway of sodium and chloride transport in corneal epithelium and endothelium, leading to hydration and edema of the cornea ${ }^{[23]}$.

Noteworthy, Wang et al. attributed the destruction, disorientation and loss of collagen fibers to apoptosis 
of keratocytes that decreased collagen production and enhancement of metalloproteinase enzyme production that degraded collagen in corneal stromal cells and increased collagen turn over with loss of stromal collagen ${ }^{[24]}$.

In addition, Descemet's membrane of the present work showed loss of endothelial cells at some portions. The altered structure and reduction of Descemet's membrane thickness resulted from failure of proto-collagen composition, cross linking of collagen and degeneration of endothelial cells ${ }^{[25]}$.

Other studies explained tissue injury by chlorinated water through the irritating effects of chlorine oxidant compounds on mucous membrane of the eye, nose and airways $^{[26,27]}$. This was due to submersion of cornea in pool water and washing away the protective tear film by chlorine that reacts with the corneal proteins, forming a layer of chloramines (disinfection by-products) on hair, skin and corneal surfaces. Chloramines trigger the eye and upper respiratory airways with damaging of tight junctions of epithelial tissue and increasing epithelial permeability ${ }^{[28]}$.

Furthermore, the effects of chlorinated water on corneas of G2 rabbits of the current study were supported immunohistochemically by a significant decrease of BCL-2 immunostaining in corneal cells.

The anti-apoptotic BCL-2 protein has an important protective role in maintaining mitochondrial structure and function, inhibiting mitochondrial permeability transition and finally prohibiting apoptosis through preventing caspase activation, as it settled the mitochondrial membrane against the release of cytocrome $\mathrm{C}^{[29]}$. Yoshizawa et.al explained the reduction of BCL-2 immunostaining by its down-regulations by the effect of chlorinated waterwhich up-regulates Bax and stimulates caspase families in corneal epithelium ${ }^{[30]}$.

Application of SH eye drops only on corneas of G3 rabbits and before chlorinated water on corneas of G4 rabbits in this work, showed marked preservation of corneal histology. The corneal structure was nearly normal with non-significant decrease in the total corneal thickness compared to G1 and G2.

These results coincided with previous researchers ${ }^{[31-33]}$ who confirmed that, $\mathrm{SH}$ acts as a tissue lubricant through its high viscosity that modulates the interactions between neighboring tissues and provides mechanical protection of corneal epithelium and endothelium. Moreover, lubricating topical SH eye drops promoted water retention on corneal surface, accelerated corneal wettability and extended the time of drug contact with cornea so; it enhanced drug bioavailability and protected ocular surface epithelium by facilitating corneal epithelial healing ${ }^{[34]}$.

IAlso, the results of this work are in agreement with the results obtained by Park et al whereas application of a lubricating $\mathrm{SH}$ eye drops at $0.5 \%$ revealed a prolonged corneal contact and conjunctival residence time that alleviates the manifestations of dry eye and provides therapeutic advantages through restoring the protective hydrating ocular tear shield and prolonging the retention time of tear film ${ }^{[35]}$.

$\mathrm{SH}$ protects the cornea against destruction through acceleration of corneal epithelial cells proliferation, decreasing the expression of inflammatory cytokines and reducing apoptosis through its antioxidant and free radical scavenging properties that absorbed the reactive oxygen species $^{[36]}$.

Moreover, hyaluronic acid has essential role in tissue regeneration through up regulation of hyaluronic acid receptors and chemotactic effects of epithelial growth factor on epithelial cells or maintaining the integrity of corneal epithelial cell proliferation to allow healing of corneal epithelial defects ${ }^{[37]}$.

Also, $\mathrm{SH}$ acts as a defensive transport vehicle by enhancing tissue repair, modulating cell migration, protein degradation and biosynthetic pathways that prevent corneal wounds ${ }^{[38]}$.

Finally, the significant increase of BCL-2 expression observed in corneal cells of G3 and G4 rabbits compared to $\mathrm{G} 2$ is in agreement with previous scientists who reported that treatment with SH suppressed apoptosis of corneal cells through conservation of BCL-2 and reducing corneal inflammation ${ }^{[39]}$.

\section{CONCLUSION}

Chlorinated water is harmful to the cornea and SH-eye drops protected it from the harmful effects of chlorine. Therefore, lubricating $\mathrm{SH}$ eye drops are recommended before swimming to flush chlorine away and allow the tear film to protect the eye.

\section{CONFLICT OF ITNEREST}

There are no conflicts of interes.

\section{REFERENCES}

1. Abdo M., Adawi M. and Kassab S. E. The effect of topical honey on the healing of cornea following alkaline injury and surgical abrasions in rats. J. Phys. Pharm. Adv. 2015, 5(10): 744-756.

2. Aldebasi YH, Nouh WG, Abdel Atti NM, Bekhit MS, Qureshi MA, Aly SM. Comparative pathological studies on the healing effect of natural (Terfezia claveryi) and synthetic (Vigamox) antimicrobials on corneal ulcers in rabbits. J. Pharm. Biomed. Sci. 2012; 2(6): 66-77.

3. Čejka Č , Ardan T, Širc J, Michálek J , Brůnová B and Čejková J. The influence of various toxic 
effects on the cornea and changes in corneal light transmission. Graefes Arch Clin. Exp. Ophthalmol.2010; 248: 1749-1756.

4. Ross M. and Pawlina W. The eye. In: Histology. A text and atlas; chapter 24; 6th ed., Philadelphia, London; Lippicott Williams and Wilkins; 2011: 896-927.

5. Gartner L. and Hiatt J.; Special Senses. In: Cell Biology and Histology; 7th ed., Wolters Kluwer Health; Philadelphia. New York. London. Sydney. Tokyo; 2015: 366-386.

6. Hasegawa T, Amako H, Yamamoto T, Tazawa M and SakamotoY. Corneal- protective effects of an artificial tear containing sodium hyaluronate and castor oil on a porcine short-term dry eye model. j. vet. med. Sci. 2014; 76(9): 1219-1224.

7. Zwiener C R S. Drowning in Disinfection byproducts? Assessing Swimming Pool Water. Environ Sci.Technology 2007;42(2): 363-72.

8. Li J-H, Wang Z-H, Zhu X-J, Deng Z-H, Cai C-X, Qiu L-Q. (2015) Health Effects from swimming training in chlorinated pools and the corresponding metabolic stress pathways. PLo S ONE 2015;10(3):1-14; e0119241.

9. LaKind JS R S. The good, the bad, the volatile: can we have both healthy pools and healthy people. Enviro. Sci. Technology 2010;44(9): 3205-10.

10. Wirostko JB, Rafii M. Sullivan DA, Morelli J, and Ding J. Novel therapy to treat corneal epithelial defects: a hypothesis with growth hormone. The Ocular Surface 2015; 13; (3): 204.e1-212.e1.

11. Beldman TJ, Senders ML, Alaarg A, Pérez-Medina C, Tang J, Zhao Y, Fay F, Deichmöller J, Born B, Desclos E, . Hyaluronan Nanoparticles Selectively Target Plaque-Associated Macrophages and Improve Plaque Stability in Atherosclerosis. ACS Nano. 2017, 27;11(6): 5785-5799.

12. Bannuru RR, Schmid CH, Kent DM. "reviews. comparative effectiveness of pharmacologic interventions for knee osteoarthritis: a systematic review and network meta-analysis". Annals of Internal Medicine 2015; 162(1): 46-54.

13. Wu CL, Chou HC, Li JM, Chen YW, Chen JH, Chen YH, Chan HL. Hyaluronic acid-dependent protection against alkali-burned human corneal cells. Electrophoresis 2013; 34(3): 388-96.
14. Ishioka $M$, Kato N, Kobayashi A, Dogru M, Tsubota K. Deleterious effects of swimming pool chlorine on the corneal epithelium. Cornea 2008; 27(1): 40-3.

15. Soliman ME, Mahmoud BL, Kafafy MA, ElHaroun HM, Mohamed DM. Histological changes in cornea following repeated exposure to benzalkonium chloride and the possible protective effect of topically applied sodium hyaluronate. Nat. Sci. 2015; 13(5): 64-76.

16. Cejka C, Luyckx J, Ardan T, Platenik J, Sirc $\mathrm{J}$, Michalek $\mathrm{J}$ and Cejkova $\mathrm{J}$. The effect of actinoquinol with hyaluronic acid in eye drops on the optical properties and oxidative damage of the rabbit cornea irradiated with UVB rays. Photochemistry and Photobiology 2010; 86: 1294-1306.

17. Bancroft JD, Layton C. The hematoxylins and eosin with Connective tissue and stains. In: Suvarna SK, Layton C, Bancroft JD. editors. Bancroft's theory and practice of histological techniques. Seventh ed., Churchill Livingstone/Elsevier, Philadelphia, 2013: 187-214.

18. Özcura F, Dündar SO, Çetin ED, Beder N, Dündar M. Effects of estrogen replacement therapy on apoptosis and vascular endothelial growth factor expression in ocular surface epithelial cells: An experimental study 2012;5(1): 64-68.

19. Bougault V and Boulet LP. Is there a potential link between indoor chlorinated pool environment and airway remodeling/inflammation in swimmers? Expert Rev. Respir. Med.2012; 6(5): 469-471.

20. Teo TL, Coleman HM, Khan SJ. Chemical contaminants in swimming pools: Occurrence, implications and control. Environ Int. 2015; 76: 16-31.

21. Richardson SD, DeMarini DM, Kogevinas M, Fernandez P, Marco E, Lourencetti C, Ballesté C, Heederik D, Meliefste K, McKague AB, Marcos R, Font-Ribera L, Grimalt JO, Villanueva CM. What is in the pool? A comprehensive identification of disinfection by-products and assessment of mutagenicity of chlorinated and brominated swimming pool water. Environmental Health Perspectives 2010; 118(11): 1523-1530.

22. Fasce F, Spinelli A, Bolognesi G, Rossi M and Gemma M. "Comparison of BD Multivise with the soft shell technique in cases with hard lens 
nucleus and Fuchs endothelial dystrophy". Eur. J. Ophthalmol. 2007; 17(5): 709-713.

23. Luyckx J, Baudouin CH. Trehalose an intriguing dissacharide with potential for medical application in ophthalmology. Clin. Ophthalmol. 2011; 5: 577-581.

24. Wang M, Li M, Yan P,Luo Q, Zhang Y, and Du $Z$. The Effect of high intensity focused ultrasound keratoplasty on rabbit anterior segment. Journal of Ophthalmology. 2017; (2017); 1-10; Article ID 6067890

25. Faried MA, Mansour FK, Zolfakar AS, El-Kholy WB. Experimentally Induced Diabetic Keratopathy in Albino Rats and the Possible Protective Role of Ginger. J Am Sci 2013; 9 (12): 206-220.

26. Chowdhury S, Alhooshani K, Karanfil T. Disinfection byproducts in swimming pool: occurrences, implications and future needs. Water Res. 2014 15; 53: 68-109.

27. Carter RAA, Joll CA. Occurrence and formation of disinfection by-products in the swimming pool environment: A critical review. J Environ Sci (China) 2017; 58: 19-50.

28. Gomà $\mathrm{A}$, de Lluis $\mathrm{R}$, Roca-Ferrer $\mathrm{J}$, Lafuente $\mathrm{J}$, Picado C. Respiratory, ocular and skin health in recreational and competitive swimmers: beneficial effect of a new method to reduce chlorine oxidant derivatives. Environ Res. 2017; 152: 315-321.

29. Zou P, Song J, Jiang B, Pei F, Chen B, Yang X, Liu $\mathrm{G}, \mathrm{Hu} \mathrm{Z}$. Epigallocatechin-3-gallate protects against cisplatin nephrotoxicity by inhibiting the apoptosis in mouse. Int. J Clin. Exp. Pathol. 2014; 7: 4607-4616.

30. Yoshizawa K, Sasaki T, Kuro M, Miki H, Kimura A, Uehara N, Yuri T and Tsubura A. Corneal damage induced in adult mice by a single intraperitoneal injection of N-Ethyl-N-Nitrosourea. In vivo. 2011; 25: 609-616.

31. Neuman MG, Nanau RM, Oruna-Sanchez $\mathrm{L}$, et al. Hyaluronic acid and wound healing. J
Pharm Pharm Sci. 2015; 18: 53-60.

32. López-de la Rosa A, Pinto-Fraga J, Arauzo FB, Rodríguez RU, González-García MJ. Safety and efficacy of an artificial tear containing $0.3 \%$ hyaluronic acid in the management of moderateto-severe dry eye disease. Eye \& contact Lens 2017 1;43(6): 383-8.

33. Zhong J, Deng Y, Tian B, et al. Hyaluronate acid-dependent protection and enhanced corneal wound healing against oxidative damage in corneal epithelial cells. J Ophthalmol. 2016; 2016: 6538051.

34. Yu F, Liu X, Zhong Y, Guo X, Li M, Mao $\mathrm{Z}$, Xiao $\mathrm{H}$ and Yang $\mathrm{S}$. Sodium hyaluronate decreases ocular surface toxicity induced by benzalkonium chloride-preserved latanoprost: An in vivo study. Invest. Ophthalmol. Vis. Sci. 2013; 54(5): 3385-3393.

35. Park Y, Song JS, Choi CY, et al. A randomized multicenter study comparing $0.1 \%, 0.15 \%$, and $0.3 \%$ sodium hyaluronate with $0.05 \%$ cyclosporine in the treatment of dry eye. J Ocul Pharmacol Ther. 2017; 33: 66-72.

36. Litwiniuk M; Krejner A; and Grzela T: Hyaluronic acid in inflammation and tissue regeneration. Wounds 2016; 28(3): 78-88 .

37. Di G, Qi X, Zhao X, Zhang S, and Zhou Q: Efficacy of Sodium Hyaluronate in Murine Diabetic Ocular Surface Diseases. Cornea 2017; 36(9): 1133-1138.

38. Araki R, Nakashima M, Teshima M, Owaki Y, Nakashima MN, Uematsu M, Kitaoka T, Nakamura T. Investigation of protective effects of sodium hyaluronate eye drop against corneal epithelial disorders using an electrophysiological method. J. Ocul. Pharmacol. Ther. 2012; 28(3): 251-8.

39. Cejka C and Cejkova J. Oxidative stress to the cornea, changes in corneal optical properties, and advances in treatment of corneal oxidative injuries. Oxidative Medicine and Cellular Longevity 2015; ( 2015): 1-10. 
الملغص العربى

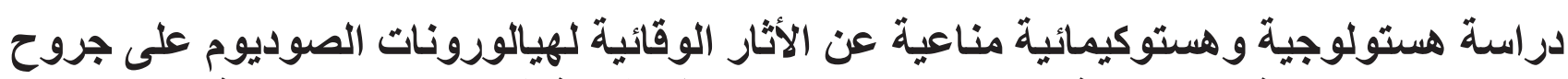

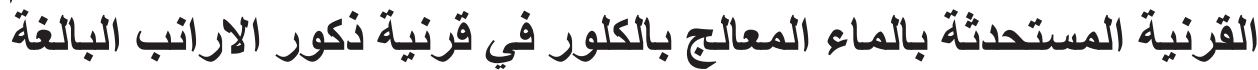

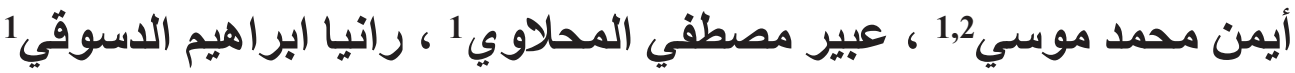

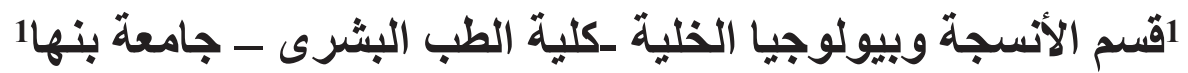 2قسم العلوم الصحية الاساسية _كلية العلوم الطبية التطبيقية_ جامعة الطبة القصيم}

المقدمة: جروح القرنية الناتجة عن التعرض للعناصر الكيمائية مثل الكلور قد تتسبب في تقليل شفافية القرنية واعاقتها. كما

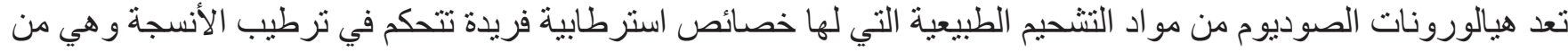
المستحضر ات الموضعية للعناية بالعين و التي تستخدم ايضا كمنتج مميز للعين.

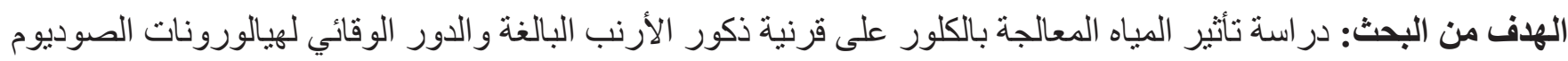
كقطره للعين في منع جروح القرنية.

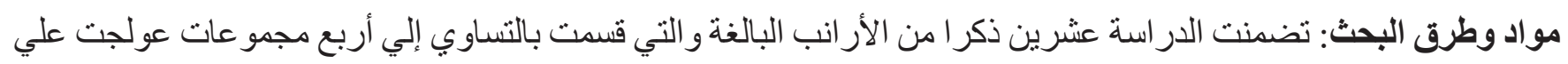

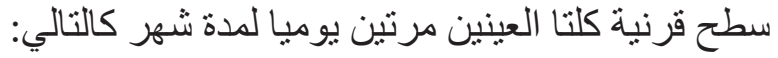

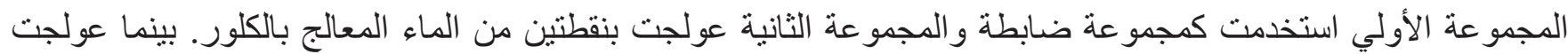

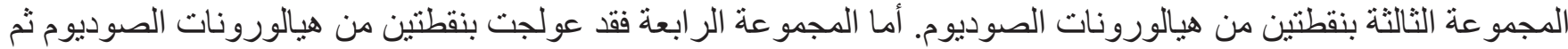

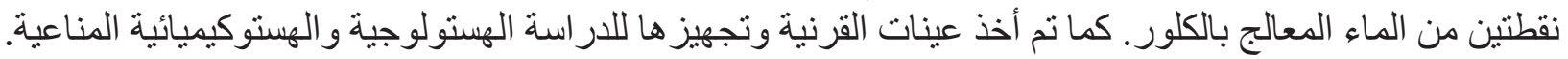

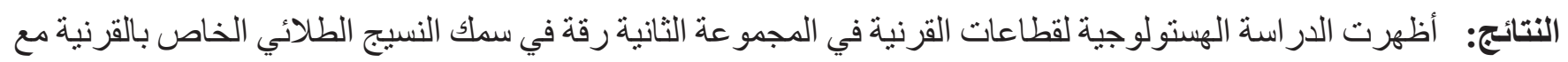

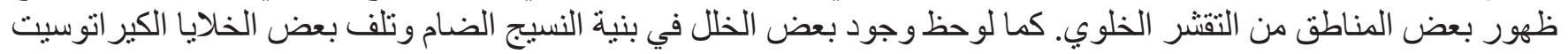

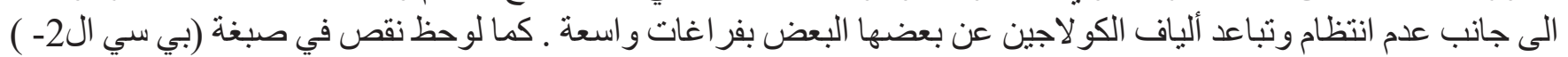
المناعية في سيتوبلازم الخلايا الظهارية. اما المجمو عة الثالثة و الر ابعة فأظهرتا تحسنا ملحوظا في جميع التغيرات التئة التي ظهرت سابقا في المجمو عة الثانية.

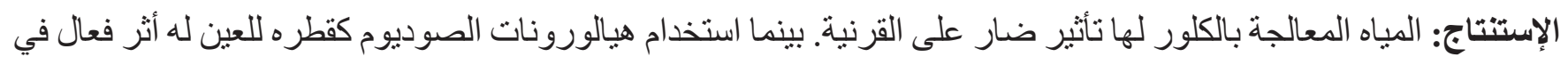

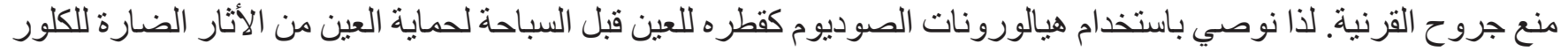
على العين و السماح لفيلم الدموع بالبقاء على سطح القرنية. 